paid to this aspect of medicine by those responsible for conducting the examination. The President undertook to raise this question at the General Medical Council. A number of replies were received which were most unsatisfactory. The three most satisfactory replies up to date came from Glasgow, Belfast and Liverpool, and it was suggested to various of the examining bodies that they might like to adopt some of the measures taken by these three Universities. The Royal College of Physicians has asked for a Delegation from the Association to meet their Planning Committee and discuss this question during the month of January, 1943.

Conference: The organization of the Conference which is to take place this afternoon with members of the following : the Public Health Services, Medical Officers of Schools Association, Children's Section of the Royal Society of Medicine and Representatives of the B.M.A. has occupied much of your Executive's time and thought. Various important officials of Public Bodies mentioned on the Agenda have been invited. The Draft Agenda was revised after a Conference with representatives of the Society of Medical Officers of Health.

\section{Other Activities :}

Members will have received a copy of the Association's Booklet, 1942/43. About one hundred copies of this booklet have been circulated with various letters and reports introducing the B.P.A.

The President contributed a most valuable article to The Times, under the title of 'The Children's Health,' on September 12, 1942, which many of you will have read with pleasure.

Members will also have noted with satisfaction that publicity has been given to various of our Memoranda in the Medical Press.

The Executive Committee has been in touch with the Child Guidance Council, and the Association's policy is that the setting up of Child Guidance Clinics should be done in close association with the Children's Departments of Teaching Hospitals or in Children's Hospitals themselves, and that such clinics should be staffed as recommended by the Child Guidance Council, i.e. with fully-trained psychiatrists, psychologists and social workers with psychiatric training, working in close cooperation with the paediatrician.

Rheumatism: The Executive is contemplating a Memorandum on Rheumatism, and various members of the Association will be asked to take part. The Secretary of this Sub-Committee is Professor Bruce Perry.

Your Executive Committee met in July, September, October, November and December. The total time during which they were in session at their meetings exceeded twenty-five hours, and the various members travelled a total distance of more than 11,000 miles. Since we last met on May 29, 1942, over 800 letters have been dispatched, either containing reports or in answer to communications, and the number of words in the memoranda which each member has received have exceeded 25,600.

Honours: Our President was congratulated by the executive committee on your behalf on being awarded by the Royal College of Physicians the Moxon medal, which is awarded every third year to the person who is deemed to have most distinguished himself by observation and research in clinical medicine, and also on being appointed first Charles West Lecturer-a lecture on Diseases of Children to be given every third year.

The Executive, on your behalf, also congratulated Professor J. C. Spence on his appointment as Professor of Child Health at Durham University.

Letters of thanks from the executive committee have been sent both to members of the Association and coopted individuals who have assisted so whole-heartedly in the preparation of the various memoranda and reports.

My grateful thanks are due to Dr. Alan Moncrieff for much help in my Secretarial work, and to my Secretary, Miss N. Hair, for her untiring efforts on the Association's behalf.

12th December, 1942.

(Signed) Donald Patersox.

It was resolved that the date and place of the next meeting be left to the Executive Committee.

Scientific proceedings: A report on the Early Diagnosis of Tuberculosis in Childhood was received and discussed. It was referred back to the sub-committee for reconsideration. Other reports, previously circulated, were discussed. These included reports on Breast feeding in relation to female labour, Safe milk, Juvenile delinquencies, Neonatal Mortality, The dosage of vitamin $D$, War-time Nurseries. (Some of these are printed below).

\title{
REPORTS OF SUB-COMMITTEES
}

At the Fourteenth Annual Meeting of the British Paediatric Association it was decided to instruct the executive committee to investigate certain problems. This has been carried out by various sub-committees and individuals, and the reports in each instance have been passed by the executive committee and submitted to the general meeting held in London on December 12, 1942.

\section{NEONATAL MORTALITY}

By C. MCNEIL (Edinburgh-Chairman), N. B. CAPON (Liverpool-Secretary), W. R. F. COLlis (Dublin), S. GRAHAM (GLASGOW) and A. MONCRIEFF (LONDON)

1. We wish to make it clear, at the outset, that when we speak of neonatal mortality we have also in mind (a) the no less important, though less sharply defined question of neonatal morbidity: and (b) the loss of potential lives by stillbirth. In regard to neonatal morbidity, it should be stressed that though young infants possess a remarkable power of recovery from trauma and illness, failure to make full recovery is especially regrettable in early life, when each individual should be entitled to the prospect of a long term of good health.

2. It is common knowledge that the gratifying decline in the infant mortality rate which has taken place in most countries during the past fifty years or more has not been accompanied by a correspondingly satisfactory fall of the neonatal mortality rate. Yet some countries and areas (e.g. Holland, Australasia, and the large cities of the U.S.A.) have been more successful in this respect than others (e.g. Scotland, England, and Wales). which shows that the problem is not insoluble.

3. In studying neonatal mortality, it is important to view the particular epoch in its relationship both to pre- $\mathbb{D}$ ceding events and to subsequent life. Without entering into detail, it is apparent that adverse influences may $\mathscr{Q}$ operate:

(a) Hereditarily.

(b) During embryonic life, e.g. congenital malforma-응 tions.

(c) During foetal life, e.g. syphilis.

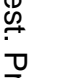


(d) By premature expulsion of the foetus in an immature state.

(e) During birth, e.g. birth-trauma; and failure of the physiological readjustments consequent upon birth.

(f) After birth, during the neonatal period, e.g. infections, lack of adequate nursing skill and care, and mismanagement and failure of breastfeeding.

4. Thus it is obvious that the problems of neonatal mortality concern not only paediatricians, but also obstetricians, general practitioners, general physicians and public health workers, and there is a need for close co-operation in study and practice. But the onus of leadership of the team should be accepted by the paediatricians who are more intimately concerned than any other group.

5. In this report we shall restrict our observations to the chief causes of neonatal mortality, which are:

(a) Immaturity (usually prematurity).

(b) Birth-trauma (especially intra-cranial haemorrhage).

(c) Respiratory difficulties arising during or immediately after birth.

(d) Infective and toxic conditions.

(e) Congenital malformations.

6. (a) To give some idea of the neonatal mortality rates per 1000 live births in different countries, the following figures are quoted, and the year to which the figure refers is given in brackets.

(By neonatal mortality is meant deaths during the first month of life.)

$\begin{array}{lcccccc}\text { Adelaide } & \ldots & \ldots & (1936) & \ldots & \ldots & 20 \\ \text { Holland } & \ldots & \ldots & (1938) & \ldots & \ldots & 21 \\ \text { Greater London } & \ldots & (1925) & \ldots & \ldots & 26 \\ \text { England } & \ldots & \ldots & (1937) & \ldots & \ldots & 24 \\ \text { Chicago } & \ldots & \ldots & (1938) & \ldots & \ldots & 26 \\ \text { Sch } & \ldots & \ldots & (1925) & \ldots & \ldots & 37 \\ \text { Gland } & \ldots & \ldots & (1937) & \ldots & \ldots & 25 \\ \text { Glasgow } & \ldots & \ldots & (1938) & \ldots & \ldots & 35 \\ \end{array}$

(b) In order to give some idea of the total numbers of deaths involved, the following facts may be of interest:

Total number of neonatal deaths in England and Wales each year about.

Total number of stillbirths in England and Wales each year about

Total number of neonatal deaths in U.S.A. each year about

Total number of stillbirths in U.S.A. each year about

7. Immaturity. This accounts for about 50 per cent. of neonatal deaths and about 50 per cent. of stillbirths. In many cases it is the primary cause of death, in others it constitutes a strong predisposing cause, because immature babies do not tolerate birth-trauma and infections as well as mature babies: their respiratory transition is hazardous and they are particularly susceptible to lack of specialized nursing care. Those who survive are prone to develop anaemia, rickets and malnutrition, especially in the less-favoured classes.

The prevention of immaturity is a problem of major importance and we recommend that new efforts should be made to solve it.

The treatment of immaturity requires special paediatric care, supported by skilled nursing (specially trained staff) in suitably equipped units: there is evidence that the usual death rate of about 50 per cent. can be reduced in this way to less than 20 per cent. The chief aims of treatment are:

(i) Maintenance of steady temperature and prevention of dehydration by special heating appliances or conditioned air.

(ii) Correct feeding (high calorie feeding and liberal fluid allowance), gavage often being necessary. (iii) Skilled nursing by a specially trained staff.

(iv) Isolation from all possible sources of infection by provision of special isolation nurseries.

A premature station or unit should be set up in every maternity hospital, and in all important children's hospitals: they should be in the charge of paediatricians possessing experience of neonatal work. Their value would not be limited to the care of the patients; they would be important teaching centres for undergraduates, postgraduates, midwives, children's nurses and health visitors.

8. Birth trauma. It is obvious that attention should be centred mainly upon prevention, which is a problem for obstetricians, general practitioners, doctors in charge of ante-natal clinics, and midwives in private practice. Paediatricians can assist by supporting all measures designed to secure first-class obstetrical practice.

9. Respiratory difficulties. The incidence of asphyxia neonatorum could probably be reduced by:

(i) Securing a higher standard of ante-natal care.

(ii) Consultations with obstetricians and physiologists in order to reach conclusions upon such points as:

(a) The use of analgesics and sedatives: and

(b) Details of ' first-aid' care of the infant including methods of resuscitation.

We desire to call attention to the lax use of the term ' asphyxia neonatorum' on death certificates, and there is little doubt that many examples of birth-trauma, neonatal pneumonia, and other conditions giving rise to (secondary) asphyxia masquerade under the title. A solution is difficult to see, but we recommend that the attention of the Registrar-General be called to the point. We also urge the importance of post-mortem examinations in cases of this type.

10. Infective and toxic conditions. Both the medical and nursing professions are still sadly ignorant about the prevalence and danger of neonatal infections, and there can be no efficient prophylaxis until this shortcoming is removed. The dangers are particularly great in institutions. Neonates should not be herded together, and this is especially necessary for those newly-born babies which are particularly prone to infections, e.g. prematures, weakly infants and those suffering with birthtrauma or congenital malformations. These should be nursed under the direction of an expert paediatrician in a special unit preferably designed on the cubicle system, and should be tended by a specially trained nursing staff, employing modern methods of prophylaxis including gowns and masks. There should be a washhand basin in each cubicle. Nurses responsible for changing the babies should not prepare nor give the feeds. A modern sterilizing apparatus should be used to disinfect napkins. A milk-kitchen is required, not only to ensure that artificial feeds are prepared accurately, and bottles are thoroughly sterilized, but to enable the nurses to receive adequate tuition in this important branch of the work, which should be supervised by a trained dietitian working under the control of the paediatrician. Breast milk is especially necessary for babies suffering with infective conditions (see para. 12), and the diets of the mothers require particular supervision (see para. 13).

11. Congenital malformations. In the present state of knowledge it is not possible to prevent congenital malformations; further research is necessary, particularly in regard to the possible influence of therapeutic agents, e.g. X-rays and radium.

12. Breast-feeding. An adequate and continuing supply of breast milk should be available for every infant, and particularly for immature, weakly, birthdamaged and ill babies. It is a tragedy that many infants are given artificial feeds, on the advice of doctors and nurses, without sufficient justification. This fact provides a strong case for better and more vigorous instruction. 
Not infrequently the supply of breast milk fails when the mother enters upon her home duties again. Planning and supervision by the family doctor or home visitor or post-natal clinic would frequently prevent this failure, particularly if the mother's diet were to receive careful attention (see para. 13), and if she were able to take sufficient rest. Too speedy a return to strenuous household duties such as washing, cooking and cleaning, results in tiredness, worry and failing health (especially anaemia): it is not surprising that breast-feeding often fails under these conditions. The psychological aspects of breast-feeding, which frequently breaks down because the mother is over-anxious, lacking in confidence, or worried, require careful consideration and should be stressed in the course of instruction given to medical students and nurses.

Breast milk banks or pools, set up in maternity hospitals or other suitable centres, would be of great value to the surrounding district and should not be difficult to maintain: the blood banks started in recent years under the stimulus of war conditions have shown what can be done by concerted and vigorous effort.

13. Diets for mothers. The health of a newly-born baby is greatly influenced by the state of the mother's health during the ante-natal period. Diet, hygiene, attention to minor ailments (e.g. dental caries and secondary anaemia) and freedom from worry are some of the subjects which need consideration by the family doctor or the ante-natal clinics. We shall speak only of diet, to which much attention has been directed of late. There is evidence that satisfactory dieting during pregnancy diminishes the incidence of still-births, promotes the general well-being of neonates and improves the mother's capacity to provide breast milk. For the poorer classes it should be possible to ensure that every pregnant woman receives a well-balanced diet of some 2500 calories with sufficient vitamins and salts each day for the three months before confinement and throughout the period of lactation. In most districts these meals could be taken in the home, but in the poorer ones it might be more suitable for one meal of roughly 900 calories to be provided each day at a communal feeding centre.

14. Some general recommendations. (a) A committee composed of paediatricians, obstetricians and public health experts (with power to co-opt other specialists as necessary) should be set up to discuss all aspects of neonatal mortality and morbidity, and to direct the further investigations which are necessary. The most important of their tasks would be to consider:

(i) The health of the pregnant woman.

(ii) The relative advantages of domiciliary and institutional confinement.

(iii) Breast-feeding.

(iv) Prevention of immaturity.

(v) Prevention of maternal and neonatal infections.

(vi) Birth injuries.

(vii) Respiratory difficulties at birth.

This committee should be empowered to advise the Minister of Health, in order that effective action may be taken.

(b) Undergraduates, postgraduates, midwives, children's nurses and health visitors are all in need of more tuition upon neonatal health and disease.

The Central Midwives Board should include at least one paediatrician, and the final examination should include questions on neonatal conditions set by a paediatrician, as is the custom in Northern Ireland.

(c) Each maternity hospital and most of the larger children's hospitals should have a properly equipped and efficiently staffed neonatal unit. These units would form part of the Department of Paediatrics in the region, and junior paediatricians would thus have better opportunities for clinical experience of the particular ageperiod. The sisters and senior nurses working in neonatal units should be qualified both as midwives and children's nurses, and their salaries should be raised accordingly.

(d) It is hoped that the setting up of a committee as recommended above would ensure the close co-operation between the Ministry of Health and local health authorities on the one hand, and paediatricians on the other, which is essential for the efficient handling of the problem.

(e) Uniform standards for statistical returns from maternity hospitals and maternity nursing homes should be secured, and there should be a more general adoption of exact standards of immaturity or prematurity, and careful and accurate returns of still-births.

\title{
THE STANDARD OF MILK SUPPLIED TO CHLDREN
}

\author{
BY A. G. WATKINS (CARDIFF)
}

(This report was based upon evidence obtained from eight areas, urban and rural. Because of the confidential nature of the replies received to a questionnaire it is not possible to publish the figures obtained.)

1. No available evidence of increase in milk-borne diseases since the war. The shifting population makes accurate statistical figures difficult to obtain, though in some areas there is a clinical impression of an increase in tuberculous glands of neck.

2. Definite lowering of bacteriological quality of milk since the war.

3. Frequent comments by medical officers of health on the unsatisfactory pasteurization of milk.

4. Likely decrease in standard of milk, especially keeping qualities, due to war-time transport problems.

\section{Recommendations:}

1. All pooled milk (other than 'reject' and 'salvage' C.M.D. 6362) to be efficiently pasteurized. Increased inspection of cooling facilities on farms and of pasteurization technique.

2. Until all milk is efficiently pasteurized, the public should be instructed to scald all liquid milk for children up to at least five years of age, but preferably dried milk should be used for infants.

3. These investigations reveal that the safeguards to ensure that pasteurization is efficient are not reliable, and it is recommended that steps be taken to remedy this state of affairs.

\section{WAR-TIME NURSERIES}

\section{BY K. D. WILKINSON (BIRMINGHAM)}

In the City of Birmingham there are at present (October, 1942) 52 nurseries in operation, accommodating 2753 children, and a further 29 are in process of formation for 1659 children. In the Midland Region (No. 9) there are:
In preparation 9 nurseries for 430 children.

Approved .. 82 ,, , 3953 ,,

Operating $\quad . .103 \quad$ ", ", 4946

Under present conditions the situation of the nurseries is governed by such considerations as suitable premises 
and the neighbouring homes of large numbers of factory workers. The result is that the nurseries have to make shift with houses which from many points of view are not ideal, and premises which have been adapted to the purpose of the nursery without great structural alteration, by the addition of baths and lavatories, and modifications in the kitchen. Indoor and outdoor play space is often limited, especially outdoor under-cover space.

The houses, schools, and other buildings are attractively clean and many have pictures and decorations of good type.

Most of the nurseries take children each day from 7 a.m. to 7 p.m. A few take children for the whole week, since the mothers are on night shifts, the children going home on Saturday and returning on Monday morning.

The children are of all ages up to five years. Some nurseries have children up to one year. Most have toddlers one to two years and seniors two to five years.

The proportion of the various groups determines the number of staff required, since up to two years the children require a lot of personal attention, washing and feeding. and after that age do most things for themselves under supervision.

I have seen the best and the worst nurseries under varying conditions of weather, and at various times of day.

Most nurseries have separate playrooms for seniors and juniors, and also separate sleeping rooms in which each child has a stretcher and two blankets marked with a name and a diagram (a blue rabbit or a red lion, and so forth) by which they are easily identified. In the playrooms are a number of indoor toys-bricks, wooden devices of various kinds, simple jigsaw puzzles. There is not enough variety as a rule, but the number of toys varies considerably at different centres. The outdoor equipment for games - chutes, climbing woodwork, boats, carts, is often quite inadequate, but in some is generous.

Washing and lavatory accommodation is good.

Food. The small children are given milk feedsalmost always prepared from dried milk - and, in addition, get an emulsion containing vitamins $A, C$ and $D$, so arranged that a teaspoonful contains 6000 A units, $1200 \mathrm{D}$ units. Breast-feeding is rare-I only saw two children so fed in several hundred-but on the other hand it is uncommon to have children under three months of age in the nursery.

Older children get a varied midday meal in addition to food at about 11 a.m. and 4 p.m. These also get the vitamin emulsion in larger doses. The midday meal is obtained from varying sources. The kitchen at the Children's Hospital feeds the nursery there and two other nurseries. Food is cooked at a central kitchen in some instances and distributed in heated containers. Many of the nurses cook their own vegetables and obtain meat from a kitchen. In a few instances a British Restaurant supplies the food.

The nursery at the Children's Hospital is on the second floor-all on one floor. It has 80 children on the books -20 under one year, 20 between one and two years, and 40 over two vears of age. The average daily attendance is 60 . One of the babies is breast-fed three times a day at present. There are 24 women staff. This includes a matron, who is a trained nurse, several with Nursery Certificates, and others in training. Their ages vary from fifteen upwards. They appeared neat and keen on the work.

Nursery ' $A$ ' is housed in a school. It has been lavishly redecorated and is spacious. Situated in the worst slum area in the city, it is particularly well equipped in all respects, and is used as an observation and training centre for teachers, and for psychological instruction of nurses and teachers.

On the other hand, the Nursery ${ }^{\prime} B$ ' is situated in a house which is essentially unsuitable, since individual rooms are small and there are three floors in use with steep stairs. This deals with twenty small children and has a staff of eleven. It was there that the difficulties presented by a shortage of elastic were obvious, for replace- ments of this material offer great difficulties, and clothing is largely suspended by elastic.

Nursery ' $C$ ' takes 53 children from two-and-a-half to five years, and has a staff of 9 . Outdoor toys are very poor. Indoor tovs were very good.

Nursery $\cdot D$ ' is a resident nursery which inhabits a school and has good accommodation. The children number 65 , of whom 7 are under one year. None is breast-fed. The staff is 15 in number. There is a garden, but there is no provision of any kind of outdoor toys for these children.

It seems to me fair to say that the Day Nurseries, as at present constituted, fill a large gap in providing care and attention for children while their mothers work, that the food is good, the supervision adequate.

I have been very much struck by the kindliness and cheerfulness of those who are doing all sorts of jobs at these Nurseries: in the course of my travels I have not seen a child in tears or heard a cross word. The only complaint was by a boy, who, having had three helpings of fish pudding, said he did not like fish!

The accommodation in many instances leaves much to be desired. Infection does occur and whooping-cough, chicken-pox and measles have been sources of trouble at one time and another. The risks of exposure are not greater in the Nursery than they are in the child's own home, since the majority of these children come from homes in which supervision is very poor.

I feel that these Nurseries are of the greatest use to the parents and a real benefit to the children. The food which is distributed to the inmates is an addition to the rations which their parents obtain for the family at home.

\section{Basis of diet}

BEFORE DINNER : Each child to have one rusk ( $\frac{1}{2} \mathrm{oz}$. of bread cut in strip and crisped in oven).

AFTER DINNER: Each child to have portion of carrot or apple to chew.

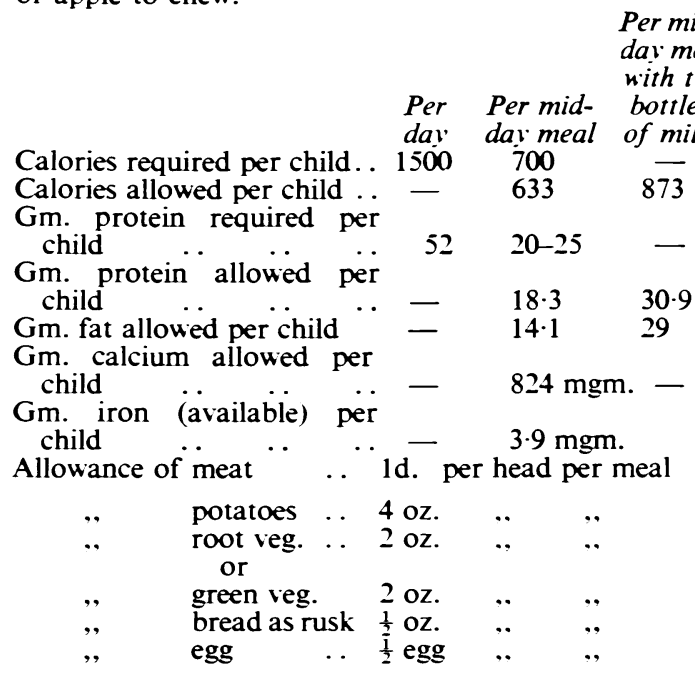

Per midayl meal ith two

Note. The Executive Committee of the British Paediatric Association considered this report on Wartime Nurseries in the Birmingham area, and as a result of these considerations and verbal reports from other areas, makes the following recommendations :-

1. As far as possible, posts as Matron or Sister in these Nurseries should be filled by trained nurses who preferably have received a children's nursing training.

2. In view of the increased risk of infection to a child in a War-time Nursery, it is strongly urged that a condition of admission should be immunisation against diphtheria.

3. It is also strongly urged that only ' safe' milk should be used in War-time Nurseries; by 'safe' milk is meant milk which has been dried, efficiently pasteurized or boiled. 


\section{THE DOSAGE OF VITAMIN D}

\section{BY W. SHELDON (LONDON-ChAIRMAN), C. F. HARRIS (LONDON), N. MORRIS (GLASGOW), and HELEN MACKAY (LONDON-CO-OPTED)}

\section{Opinions on vitamin $D$ requirements of infants and children}

(a) The minimum requirement for infants and children is not known.

(b) The Technical Commission on Nutrition of the League of Nations (1938) place the requirements of infants at 400-500 i.u. daily.

(c) The Committee of Food and Nutrition of the National Research Council in the U.S.A. and the Committee on Vitamins of the American Academy of Paediatrics (Dann and Davison, 1942) put the requirements of children from birth up to fifteen years of age at 400-800 i.u. daily.

(d) The figure in (c) has been endorsed by the National Nutrition Conference for Defence (1941) summoned by President Roosevelt.

(e) Eliot and Park (1942) consider that 800-1000 i.u. daily cover any possible requirement of full-term infants.

(f) At St. Bartholomew's Hospital, London, for the last ten years, it has been the practice to give daily doses of 600 i.u. as cod-liver oil to infants prophylactically.

(g) Premature infants (i.e. infants whose birth weight is below $5 \frac{1}{2} \mathrm{lb}$.), vary more widely in their individual requirements than full-term infants, but their need is uniformly higher. Their daily routine allowance should be twice that of full-term infants, and should be continued at this rate until their second birthday.

(h) The incidence of active rickets is as great under six months of age as over. In view of the more active growth rate in the earlier months of life, the prophylactic requirement of vitamin $D$ is greater in these months.

(i) In summer in Great Britain, sunshine and skyshine can generally be relied upon to protect full-term infants from rickets, provided they are suitably exposed to those elements for at least four hours daily. This provision cannot, however, be expected to be uniformly available, especially under the difficult conditions of war-time. In winter little vitamin $\mathrm{D}$ is rendered available by natural irradiation. This sub-committee therefore considers that seasonal variations in vitamin $\mathrm{D}$ allowance would be unwise.

(j) With regard to children beyond the age of infancy, who are receiving a mixed diet, the amount of vitamin D obtainable from their food is subject to such variation and, in any case, is so small that a deduction in the amount of vitamin D supplement is considered to be unjustified.

(k) With regard to infants, this report does not distinguish between those who are breast-fed and those artificially reared, the sub-committee being of the opinion that a supplementary ration of vitamin $D$ should be issued impartially to both groups of infants, irrespective of whether or not nursing mothers are to be allowed a vitamin D supplement.

\section{The present official dosage of 'cod-liver oil compound'}

The cod-liver oil compound supplied by the Government as a supplementary ration for children under five years of age, contains ' not less than 100 i.u. of vitamin D per gramme.' The maximum dosage for children under six months old is 'half a teaspoonful daily,' and for those over six months, "one teaspoonful." On a generous interpretation, this provides 200 i.u. daily under six months of age, and 400 i.u. daily for older infants. It would be hard to find any authority with clinical experience to support so small a dose. Moreover, it will be noted that infants under six months are allowed a smaller dose than older babies, which does not accord with their actual needs.

\section{Recommendations re dosage of vitamin D}

A daily allowance under the Government scheme should be sufficient to protect practically all babies under the varying circumstances of their lives, without further addition of vitamin $D$, obtained through private channels.

(a) FULL-TERM INFANTS AND CHILDREN LP TO FIVE YEARS OLD.

Although a daily intake of 500 i.u. would probably protect the majority of full-term infants and voung children, a daily allowance of 700 i.u. would give a wider $\omega$ margin of safety. For simplicity in administration, a 'vitaminized 'oil should be so reinforced with irradiated ergosterol that 1 fluid drachm contains the daily allowance of 700 i.u. - as well as the 3500 i.u. of vitamin A $\vec{\infty}$ now provided in each drachm.

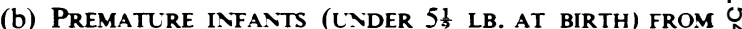
BIRTH TO TWO YEARS.

The allowance should be double that in paragraph 3 (a), i.e. a daily allowance of 1400 i.u., contained in 2 fluid drachms of ' vitaminized' oil.

\section{(c) SCHOOL CHILDREN}

Information regarding the vitamin $\mathrm{D}$ needs of school children is meagre, although there is much to suggest that vitamin $D$ deficiency is one factor in the etiology of dental caries in our school children. Taking also into consideration the small amount of fat, fish, eggs and meat fat that are available, it is recommended that a supplement of 3500 i.u. of vitamin D per week be allowed for this group of children. Administratively, this supplement might be issued with school milk, or through the medium of school dinners.

(d) Pregnant and Nirsing women.

It is recommended that a supplement of $700 \mathrm{i} . \mathrm{u}$. of $\supset$ vitamin $\mathrm{D}$ daily be allowed to this group of the community. The provision of such a supplement should not do away with the supplement for breast-fed infants.

\section{Suggestions concerning routine administration of $\bar{O}$} vitamin D

Printed directions for the mother should be issued o with the ration of vitamin $D$. These should include :

(a) Instructions to start the oil gradually, beginning with a few drops daily when the infant is a month old, and taking a fortnight to work up to the full dose of $D$ one teaspoonful ( 700 i.u. daily).

(b) Inform her that for an infant whose weight at birth is over $5 \frac{1}{2} \mathrm{lb}$. the supplement of vitamin $D$ need $\sigma$ not be given on summer days, provided the infant is $N$ out of doors morning and afternoon.

(c) Warn her that an infant whose birth weight is $\mathrm{N}$ below $5 \frac{1}{2} \mathrm{lb}$. is particularly susceptible to rickets: that $\sigma$ the allowance of vitamin D supplement must therefore be doubled to 2 teaspoonfuls daily, and that this should $\stackrel{\varrho}{\subset}$ be divided into four equal doses each day, and begun $\Phi$ gradually: and that this supplement should be given $?$ throughout summer and winter: and that all premature $T$ babies should be under regular medical supervision.

For the information of doctors, the composition and $\vec{D}$ vitamin content of " cod-liver oil compound" should be $\Omega$ given on the label, and published in the medical press.

5. Recommendations to the executive committee of the British Paediatric Association as to procedure that $\delta$ might be adopted with this report

(a) Assuming that the executive committee accept this report, it should be forwarded to the Minister of 
Health, the Minister of Food, and the Minister of Education, asking for their co-operation in putting the recommendations into practice.

(b) That either the whole report, or an abstract of the recommendations, be published in the medical press, including the public health journals, and be sent to the nursing journals.

(c) That copies be circulated to the members of the British Paediatric Association, and to the members of the Society of Medical Officers of Health.

\section{References}

Dann, W. J. and Davison, W. C. (1942). Amer. J. Dis. Child., 63, 366.

Eliot, M. M., and Park, E. A. (1942). Practice of Pediatrics, edited by Brennemann, J., Maryland, $1,97$.

National Nutrition Conference for Defence (1941). Public Health Rep., 56, 1233.

Technical Commission on Nutrition (1938). Bull. Health Organisation, League of Nations, 7, 460.

\section{BREAST-FEEDING IN RELATION TO FEMALE LABOUR AS IT PARTICULARLY AFFECTS BIRMINGHAM}

\section{By A. V. NEALE (BIRMingham), ETHEL CASSIE (BIRMINGHAM, CO-OPTED), FRANCES BRAID (BIRMINGHAM, CO-OPTED) AND MILA PIERCE (CHICAGo, CO-OPTED)}

Following a request from the executive committee of the British Paediatric Association, in July, 1942, a committee was formed, to investigate breast-feeding, in the City of Birmingham, with a special reference to the relationship to female labour. We are greatly indebted to the Health Visitors (100) working in the Department of Maternity and Child Welfare. Those visitors were asked to report on the babies born during the first quarter of 1941, and of 1942. Each Health Visitor was given a form setting out the information required, as detailed in the questionnaire, as follows:

\section{QUESTIONNAIRE TO COVER RETURN FORM}

First or later child.

Period of breast-feeding.

Mother working or not during pregnancy.

If so how long.

Mother working after confinement.

If so how soon.

If not, is she anxious to commence, or does she wish to postpone until normal breast-feeding period is over.

They also received a personal explanation from the Superintendent Health Visitor, in regard to the exact requirements, special emphasis being given to the reasons why the information was wanted, in order to obtain enthusiastic co-operation. The schedules were to be returned within six weeks. At the end of the period, those schedules which had not been sent in were looked up, and a certain number had to be returned for further information. The Superintendent of the Health Visitors incorporated the schedules to obtain the figures utilized in this report. We emphasize that this required considerable extra efforts in the Health Visitors' work. Records of 4635 babies were obtained. In addition to the statistics some comments are included, which were obtained in a personal discussion, by Dr. Ethel Cassie at a general meeting of Health Visitors; the observations set out were unanimous.

\section{Notes on Discussion with Superintendent Health Visitors, 19th February, 1942}

1. The incidence of breast-feeding is not materially affected by the present situation. In the areas where married women were not accustomed to working in the factories, they are not going into the factories while they have a baby under one year. In the areas where they were accustomed to working before the war, the women go out as before, but usually at no earlier date, i.e. they wait until the baby is a couple of months old at least. This is borne out by the admissions to war-time nurseries. Young babies are coming in very small numbers. It is only in poor districts that the number of babies is more than one-fifth of the total. Even then, it is rare to have an infant under three months.

2. Present influences, which are adverse to breast feeding are:

(a) Queueing for shopping. (b) Emotional disturbances, particularly anxiety as to husbands.

(c) Part-time work, liability to supplementary feeding.

(d) Doctors are still responsible for weaning babies more than any other single factor. They still take babies off the breast, whenever there is any difficulty, rather than take the trouble to go into the whole difficult question of successful breastfeeding. Doctors were named who made a practice of this.

Babies are doing very well, better than before the war, and the general feeling is that breast-feeding has not gone down.

Where the men are at home, and on munition work, as they are in large districts of the City, there is more money going into the homes, and the women are in such circumstances disinclined to go out to work, and the infants are, on the whole, better cared for than in the past.

A further enquiry was made by Dr. Mila Pierce in the out-patients' department of the Birmingham Children's Hospital, and her findings are included in the report.

We should state that a prior enquiry was made in 1938, in reference to babies born in January to June, 1937. A copy of these statistics are enclosed in this report (table 1).

It is interesting to note that the incidence of breastfeeding (wholly or partly) for three to six months, was 51 per cent., whereas in the 1941 and 1942 enquiry, it was practically the same- 53 per cent. This indicates that in the pre-war periods there appears no obvious factor altering the incidence of breast-feeding to any appreciable degree. Some observations were made in 1938 in regard to the reason for the limited incidence of breast-feeding or its abandonment. Table 2 indicates the details.

It will be noted that in the 1939 series, 15 per cent. gave up breast-feeding because of going to work. In the present series, only 11 per cent. gave a similar reason. This would seem to be a reflection of the diminished family financial embarrassments in the munition worker group.

Comparison shows that in the earlier weeks the first baby is at a disadvantage as compared with the second or later baby: but after two months this difference disappears. This may bear some relationship to a lesser degree of maternal anxiety in the second or later pregnancy.

Working in pregnancy appears to have little influence in regard to subsequent breast-feeding. It is interesting to note that only a small proportion are anxious to return to work: and these are mainly unmarried mothers or women in key positions. The actual numbers returning to work are small, and only amount to approximately 12 per cent.

Since only 12 per cent. are working after confinement, it appears that women, as a whole, prefer to stay at home with their infants when economic circumstances are favourable. There is corroborative evidence of this in Dr. Pierce's cases. The same point is revealed in the small number of young infants admitted to Day Nurseries, although they are accepted from the age of one month. It has been noted that the only nurseries where the larger 
TABLE 1

BREAST-FEEDING RECORD OF CHILDREN BORN JANUARY TO JUNE, 1937 (Children living January, 1938)

\begin{tabular}{|c|c|c|c|c|}
\hline $\begin{array}{l}\text { Total number of cases reported by Health } \\
\text { Visitors }\end{array}$ & $\begin{array}{c}(1) \\
\text { Inner circle } \\
12 \text { centres } \\
2023\end{array}$ & $\begin{array}{l}\text { (2) } \\
\text { Outer circle } \\
21 \text { centres } \\
2355\end{array}$ & $\begin{array}{l}\text { (3) } \\
\text { Total of Col. } \\
\text { (1) and (2) } \\
4378\end{array}$ & $\begin{array}{l}\text { Total per cent. of } \\
\text { all babies of corre- } \\
\text { sponding age }\end{array}$ \\
\hline \multirow[t]{2}{*}{$\begin{array}{l}\text { Breast-fed: } \\
1 \text { month or less wholly } \\
\qquad, \quad, \quad \text { partly }\end{array}$} & \multirow[t]{2}{*}{$\begin{array}{r}1543 \\
206\end{array}$} & \multirow[t]{2}{*}{$\begin{array}{r}1855 \\
225\end{array}$} & $\begin{array}{r}3398 \\
431\end{array}$ & \\
\hline & & & 3829 & 87 \\
\hline \multirow[t]{2}{*}{$\begin{array}{c}1 \text { to } 2 \text { months wholly } \\
\text {, , partly }\end{array}$} & \multirow[t]{2}{*}{$\begin{array}{r}1162 \\
262\end{array}$} & \multirow[t]{2}{*}{$\begin{array}{r}1355 \\
372\end{array}$} & $\begin{array}{r}2517 \\
634\end{array}$ & \\
\hline & & & 3151 & 72 \\
\hline \multirow[t]{2}{*}{$\begin{array}{c}2 \text { to } 3 \text { months wholly } \\
,, \quad, \quad \text { partly }\end{array}$} & \multirow[t]{2}{*}{$\begin{array}{l}914 \\
295\end{array}$} & \multirow[t]{2}{*}{$\begin{array}{r}1094 \\
304\end{array}$} & $\begin{array}{r}2008 \\
599\end{array}$ & \\
\hline & & & 2607 & 60 \\
\hline \multirow[t]{2}{*}{$\begin{array}{c}3 \text { to } 6 \text { months wholly } \\
,, \quad \text {,, partly }\end{array}$} & $\begin{array}{l}751 \\
283\end{array}$ & $\begin{array}{l}881 \\
336\end{array}$ & $\begin{array}{r}1632 \\
619\end{array}$ & \\
\hline & & & 2251 & 51 \\
\hline
\end{tabular}

Children not breast-fed at first visit-549, or 13 per cent. of total.

TABLE 2

BREAST-FEEDING RECORD OF CHILDREN BORN JANUARY TO JUNE, 1937

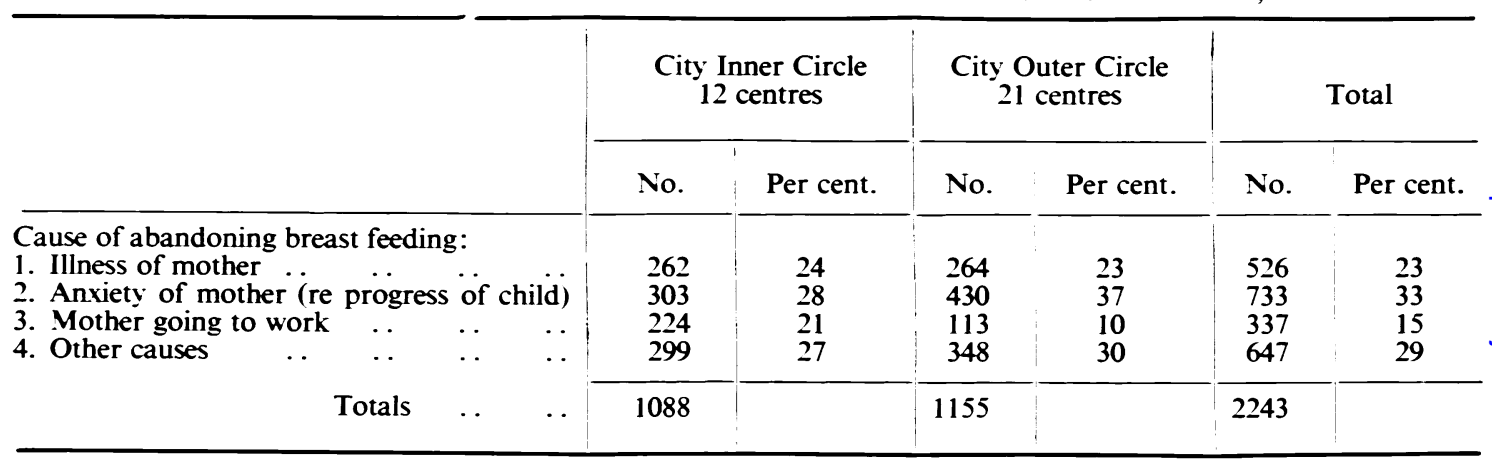

number of infants are admitted are situated in the districts where the women were accustomed to go out to work before the war; and, incidentally, where the infant mortality rates were high.

\section{Special comments on Table 3}

The table set out shows the following points of interest:

(1) THE PERCENTAGE OF INFANTS EITHER NOT BREASTFED OR BREAST-FED FOR LESS THAN ONE MONTH. The weaning of these cases took place before the health visitor was able to exert any influence on the result, and therefore occurred under the influence of the doctor or midwife. In 1941 the percentage was 7.9 per cent., and in 1942 it was 7.2 per cent. It is believed that a high percentage of these cases are among the unmarried mothers. There is a comparable figure available for Birmingham. We find that in 1938, 13 per cent. of the infants were not breast-fed at the age of one month, so that the present result is actually much better than in the past. The improvement among the married group is greater still, since there has been a definite increase in illegitimate births.
ILLEGITIMATE BIRTHS. FIRST QUARTER. BORN IN BIRMINGHAM

$\begin{array}{lllll}\text { YEAR } & & & & \text { No. } \\ 1938 & \ldots & \ldots & \ldots & 180 \\ 1939 & . . & \ldots & \ldots & 178 \\ 1940 & . & \ldots & \ldots & 176 \\ 1941 & \ldots & \ldots & \ldots & 169 \\ 1942 & \ldots & \ldots & \ldots & 239\end{array}$

(2) THE TOTAL BABIES FED UP TO, AND OVER, THREE MONTHS.

$1941 \quad$. 53 per cent. $1942 \quad \ldots \quad 52$ per cent.

This figure shows no material difference from the $\mathbb{D}$ results obtained in the 1938 enquiry, when it was found that 51 per cent. of the children were still on the breast $\varrho$ from three to six months. The above figures suggest that $\bar{Y}$ more breast-feeding is being carried out at the present time than before the war. This may be associated with o better economic conditions in many homes. The difference between the first and later infants is not very material. 
TABLE 3

BREAST-FEEDING INVESTIGATION, 1942

First QUARTER OF 1941: Total number investigated, 1937.

\begin{tabular}{|c|c|c|c|c|c|c|c|c|c|c|c|c|c|}
\hline & \multirow{3}{*}{$\begin{array}{l}\text { Per } \\
\text { cent. } \\
\text { of 1st } \\
\text { or } \\
\text { later } \\
\text { chil- } \\
\text { dren }\end{array}$} & \multirow{3}{*}{$\begin{array}{l}\text { No. of } \\
\text { chil- } \\
\text { dren }\end{array}$} & \multicolumn{5}{|c|}{ Working in pregnancy } & \multirow{3}{*}{$\begin{array}{l}\text { Anxi- } \\
\text { ous to } \\
\text { return }\end{array}$} & \multicolumn{5}{|c|}{ Mother working after confinement } \\
\hline & & & \multicolumn{3}{|c|}{$\begin{array}{l}\text { Up to (No. } \\
\text { of weeks) }\end{array}$} & \multirow{2}{*}{$\begin{array}{c}\text { Over } \\
32 \\
\text { weeks }\end{array}$} & \multirow{2}{*}{ Total } & & \multirow{2}{*}{ month } & \multirow{2}{*}{ month } & \multirow{2}{*}{$\begin{array}{c}\text { 3rd } \\
\text { month }\end{array}$} & \multirow{2}{*}{ later } & \multirow{2}{*}{ Total } \\
\hline & & & 24 & 28 & 32 & & & & & & & & \\
\hline $\begin{array}{l}\text { Not breast-fed or for less } \\
\text { than } 1 \text { month: } \\
\begin{array}{l}\text { First baby } \\
\text { 2nd or later children }\end{array}\end{array}$ & $\begin{array}{c}10 \\
5 \cdot 4\end{array}$ & $\begin{array}{r}100 \\
51\end{array}$ & $\begin{array}{r}10 \\
5\end{array}$ & 1 & $=$ & 1 & $\begin{array}{r}12 \\
5\end{array}$ & $\begin{array}{l}8 \\
5\end{array}$ & 1 & $\begin{array}{l}1 \\
4\end{array}$ & $\frac{3}{-}$ & $\begin{array}{l}7 \\
2\end{array}$ & $\begin{array}{r}12 \\
6\end{array}$ \\
\hline $\begin{array}{l}\text { Breast-fed up to } 1 \text { month: } \\
\text { First baby } \\
\text { 2nd or later children }\end{array}$ & $\begin{array}{l}27 \\
22\end{array}$ & $\begin{array}{l}274 \\
207\end{array}$ & $\begin{array}{l}28 \\
14\end{array}$ & $\begin{array}{r}13 \\
7\end{array}$ & $\begin{array}{l}7 \\
2\end{array}$ & $\begin{array}{l}5 \\
1\end{array}$ & $\begin{array}{l}53 \\
24\end{array}$ & $\begin{array}{l}22 \\
19\end{array}$ & $\begin{array}{l}6 \\
2\end{array}$ & $\begin{array}{l}3 \\
1\end{array}$ & $\begin{array}{l}9 \\
3\end{array}$ & $\begin{array}{l}23 \\
12\end{array}$ & $\begin{array}{l}41 \\
18\end{array}$ \\
\hline $\begin{array}{l}\text { Breast-fed up to } 2 \text { months: } \\
\text { First baby } \begin{array}{l}\ldots \\
\text { 2nd or later children }\end{array}\end{array}$ & $\begin{array}{l}13 \\
15\end{array}$ & $\begin{array}{l}129 \\
141\end{array}$ & $\begin{array}{r}21 \\
9\end{array}$ & $\begin{array}{l}8 \\
9\end{array}$ & $\begin{array}{l}4 \\
1\end{array}$ & $\begin{array}{l}6 \\
1\end{array}$ & $\begin{array}{l}39 \\
20\end{array}$ & $\begin{array}{r}13 \\
9\end{array}$ & - & $\begin{array}{l}1 \\
5\end{array}$ & $\begin{array}{l}6 \\
1\end{array}$ & $\begin{array}{r}8 \\
10\end{array}$ & $\begin{array}{l}15 \\
16\end{array}$ \\
\hline $\begin{array}{l}\text { Breast-fed up to } 3 \text { months: } \\
\text { First baby } \begin{array}{l}\ldots \\
\text { 2nd or later children }\end{array}\end{array}$ & $\begin{array}{l}11 \\
11.5\end{array}$ & $\begin{array}{l}114 \\
108\end{array}$ & $\begin{array}{l}23 \\
11\end{array}$ & $\begin{array}{l}9 \\
1\end{array}$ & $\begin{array}{l}1 \\
1\end{array}$ & 二 & $\begin{array}{l}33 \\
13\end{array}$ & $\begin{array}{r}10 \\
5\end{array}$ & - & $\overline{1}$ & 4 & $\begin{array}{r}10 \\
9\end{array}$ & $\begin{array}{l}14 \\
10\end{array}$ \\
\hline $\begin{array}{l}\text { Breast-fed over } 3 \text { months: } \\
\text { First baby } \quad{ }^{2 n d} \text { or later children }\end{array}$ & $\begin{array}{l}38 \\
45\end{array}$ & $\begin{array}{l}384 \\
429\end{array}$ & $\begin{array}{l}46 \\
18\end{array}$ & $\begin{array}{l}23 \\
11\end{array}$ & $\begin{array}{r}11 \\
2\end{array}$ & $\begin{array}{l}2 \\
4\end{array}$ & $\begin{array}{l}82 \\
35\end{array}$ & $\begin{array}{l}18 \\
24\end{array}$ & 1 & $\begin{array}{l}4 \\
2\end{array}$ & $\begin{array}{r}4 \\
13\end{array}$ & $\begin{array}{l}47 \\
45\end{array}$ & $\begin{array}{l}56 \\
60\end{array}$ \\
\hline $\begin{array}{l}\text { Total investigated: } \\
\text { Total first babies } \\
\text {," later babies }\end{array}$ & $\begin{array}{r}1001 \\
936\end{array}$ & 1937 & 185 & 82 & 29 & 20 & 316 & 133 & 40 & 22 & 43 & 173 & $\begin{array}{l}248 \\
12 \text { per } \\
\text { cent. }\end{array}$ \\
\hline
\end{tabular}

FIRST QUARTER of 1942: Total number investigated 2698 cases.

Not breast-fed or for less than 1 month:

First baby

2nd or later children

Breast-fed up to 1 month: First baby
2nd or later children

Breast-fed up to 2 months: First baby

2nd or later children

Breast-fed up to 3 months:

First baby

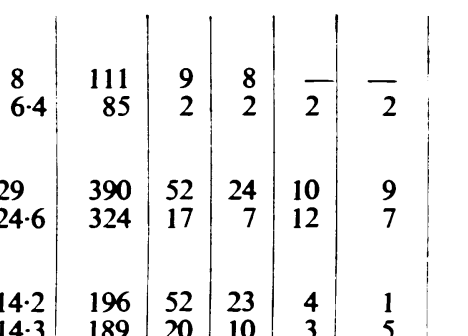

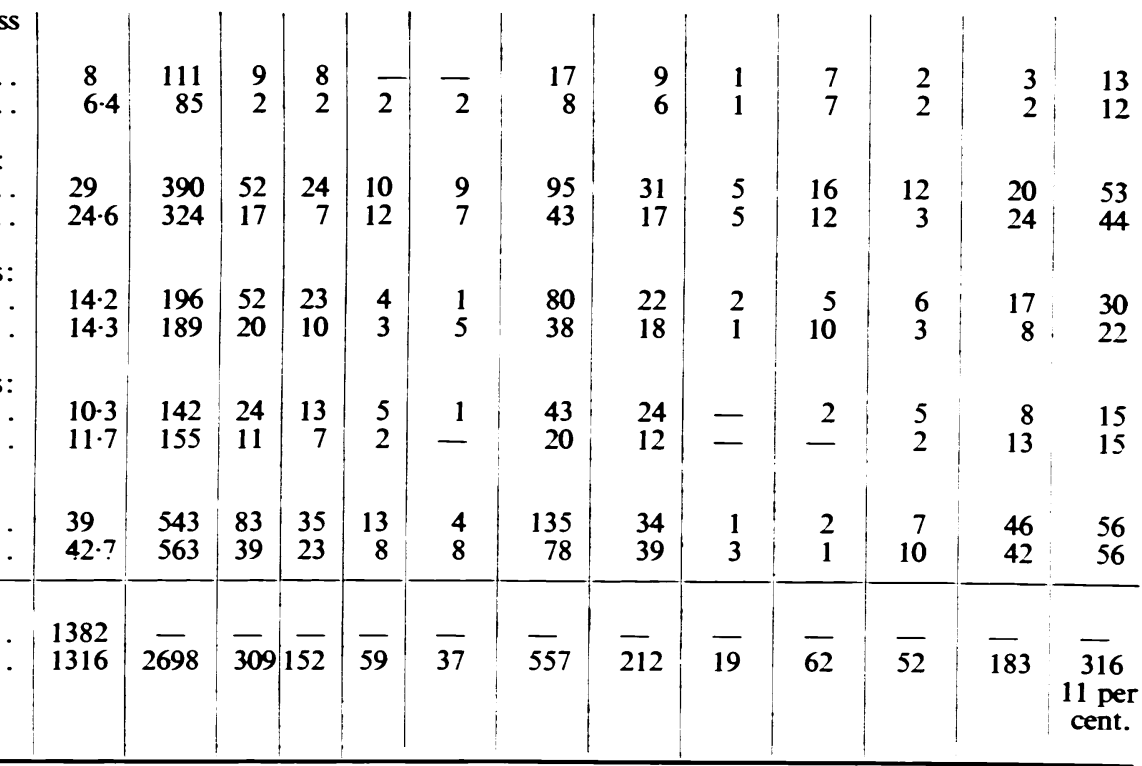

Breast-fed over 3 months:

First baby

2nd or later children .

Total investigated:

Total first babies

, later babies 
Only fifteen cases were definitely quoted in which a mother who had not breast-fed her first infant was successful with a later child. One would, of course, expect some improvement with second and subsequent children.

(3) WORK IN RELATION TO BREAST-FEEDING. It is SUIprising to find the small percentage (16 per cent.) of women actually working during pregnancy. This percentage is further decreased when the figures for the earlier weeks are omitted. Two per cent. only were working after twenty-eight weeks' pregnancy. The influence of the work during pregnancy can be considered to have little effect on the final totals.

(4) WEANING DUE TO ANXIETY TO RETURN TO WORK. It was repeatedly emphasized that this was mainly among the unmarried mothers.

(5) WEANING THE CHILD IN ORDER TO RETURN TO WORK. Only a comparatively low percentage return to work after confinement until the child is over the age of six months. It is rather that when the child is weaned the mother thinks of working. As long as the child is thriving on the breast, she does not consider the question seriously.

The report of Dr. Pierce is concerned with 164 babies, brought to the casualty and out-patient department of the Children's Hospital. The contrast between these, and the welfare department details, emphasizes the fact that these figures are taken in a specially selected group of the baby population. In view of this, independent comment is made in Dr. Pierce's cases.

The following is an analysis of an enquiry regarding the duration of breast-feeding in babies brought to the out-patient department of the Birmingham Children's Hospital during September, 1942. It is submitted in spite of the small number of cases, since it represents a different cross section of the baby population of the city than the welfare group.

\section{Total number of babies, included in the survey-164}

$$
\begin{aligned}
& \begin{array}{lllllll}
1 \text { st born } & \ldots & \ldots & \ldots & \ldots & \ldots & 80
\end{array}
\end{aligned}
$$

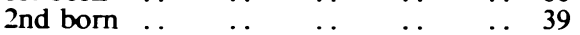

$$
\begin{aligned}
& \text { 3rd or later sibling } \quad \ldots \quad \ldots . \quad \ldots \quad 45 \\
& \text { Total .. } 164
\end{aligned}
$$

2. Selection of cases. Consecutive babies under one year of age, seen in the casualty office, and in the surgical clinic, were included in the survey. They fall into two groups, the 'sick' and the 'well ' groups, and the findings are analysed with this in mind. The 'sick' babies are those whose presenting complaint was such that it affected the general health and nutrition. The "well' group are those whose complaint did not affect their general well-being.

\section{(A) Diagrosis:}

\section{Sick Babies}

Gastro-enteritis

Upper respiratory in-

fections and otitis

Skin infections

Whooping cough .

Abscesses ... ...

Nephritis $\quad \ldots \quad \ldots \quad 1$

Anaemia $\quad \ldots \quad$.. 1

$$
\text { Total .. } \overline{76}
$$

(B) Age (at date of INTerview):

(i) Actual average age: 88 Well babies..

76 Sick babies ..

164 Total group
. 4 months 27 days

.. 4 months 4 days

\begin{tabular}{|c|c|c|c|c|}
\hline \multirow[b]{2}{*}{ Age } & \multicolumn{2}{|c|}{ Well babies } & \multicolumn{2}{|c|}{ Sick babies } \\
\hline & No. & Percentage & No. & Percentage \\
\hline \multirow{2}{*}{$\begin{array}{l}\text { Birth: } \\
2 \text { weeks .. } \\
\text { 2-4 weeks } \\
\text { 1-2 months } \\
\text { 2-3 months } \quad . . \\
\text { Total no. and per cent. } \\
\text { under } 3 \text { months .. } \\
\end{array}$} & $\begin{array}{r}-2 \\
6 \\
15\end{array}$ & $\begin{array}{r}\overline{2 \cdot 27} \\
2 \cdot 81 \\
17 \cdot 04\end{array}$ & $\begin{array}{r}-3 \\
17 \\
11\end{array}$ & $\begin{array}{r}\overline{3 \cdot 94} \\
22 \cdot 36 \\
14 \cdot 47\end{array}$ \\
\hline & 23 & $26 \cdot 12$ & 31 & $40 \cdot 77$ \\
\hline \multirow{2}{*}{$\begin{array}{c}\text { 3-4 months } \\
\text { 4-5 months } \\
\text { 5-6 months } \\
\text { Total no. and per cent. } \\
\text { under } 6 \text { months } \\
\text { un }\end{array}$} & $\begin{array}{r}11 \\
17 \\
8\end{array}$ & $\begin{array}{r}12 \cdot 50 \\
19 \cdot 31 \\
9 \cdot 09\end{array}$ & $\begin{array}{l}8 \\
7 \\
7\end{array}$ & $\begin{array}{r}10 \cdot 50 \\
9 \cdot 21 \\
9.21\end{array}$ \\
\hline & 59 & $67 \cdot 02$ & 53 & $69 \cdot 71$ \\
\hline \multirow{2}{*}{$\begin{array}{l}\text { 6-9 months } \\
\text { Total no. and per cent. } \\
\text { under } 9 \text { months } . .\end{array}$} & 18 & $20 \cdot 45$ & 11 & $14 \cdot 47$ \\
\hline & 77 & $87 \cdot 47$ & 64 & 84.18 \\
\hline \multirow{2}{*}{$\begin{array}{c}9-12 \text { months } \\
\text { Total no. and per cent. } \\
\text { under } 1 \text { year }\end{array}$} & 11 & $12 \cdot 50$ & 12 & $15 \cdot 79$ \\
\hline & 88 & $999 \cdot 7$ & 76 & $99 \cdot 97$ \\
\hline
\end{tabular}

. 4 months $15 \cdot 5$ days (ii) RANGE (IN MONTHS)

Among the sick infants, 40 per cent. were under 3 months, $69 \cdot 71$ per cent. under 6 months: the number over 6 months was small, equalling 30 per cent. of the whole. As compared with well babies, the proportion is similar over six months, but under three months there is a marked preponderance of sick babies; this is equalized in a three-to-six-month group.

\section{Duration of breast-feeding.}

\begin{tabular}{|c|c|c|c|c|c|c|}
\hline \multirow{2}{*}{$\begin{array}{l}\text { Age when } \\
\text { weaned }\end{array}$} & \multicolumn{3}{|c|}{ Well babies } & \multicolumn{3}{|c|}{ Sick babies } \\
\hline & No. & $\begin{array}{c}\text { Per } \\
\text { cent. }\end{array}$ & $\begin{array}{l}\text { Per } \\
\text { cent. }\end{array}$ & No. & $\begin{array}{l}\text { Per } \\
\text { cent. }\end{array}$ & $\begin{array}{l}\text { Per } \\
\text { cent. }\end{array}$ \\
\hline $\begin{array}{l}\begin{array}{l}\text { Never put to } \\
\text { breast }\end{array} \\
2 \text { weeks or earlier }\end{array}$ & $\begin{array}{r}11 \\
5 \\
- \\
\end{array}$ & $\begin{array}{c}12 \cdot 50 \\
5 \cdot 69 \\
- \\
\end{array}$ & $\overline{-}$ & $\begin{array}{r}8 \\
7 \\
- \\
\end{array}$ & $\begin{array}{c}16 \cdot 52 \\
9 \cdot 21 \\
- \\
\end{array}$ & $\begin{array}{c}\overline{-} \\
19 \cdot 73 \\
\end{array}$ \\
\hline 2 to 4 weeks & - & $\begin{array}{c}15.90 \\
- \\
\end{array}$ & $3 \overline{34.08}$ & 22 & $\begin{array}{c}28.94 \\
- \\
\end{array}$ & $\overline{48.67}$ \\
\hline $\begin{array}{l}1-2 \text { months } \\
2-3 \quad,, \\
\end{array}$ & $\begin{array}{l}17 \\
11 \\
\end{array}$ & $\begin{array}{l}19 \cdot 23 \\
12 \cdot 5 \\
\end{array}$ & - & $\begin{array}{r}18 \\
6 \\
\end{array}$ & $\begin{array}{r}23 \cdot 68 \\
7 \cdot 89 \\
\end{array}$ & - \\
\hline $\begin{array}{c}\text { Per cent. weaned } \\
\text { by end of } 3 \\
\text { months }\end{array}$ & - & - & $65 \cdot 81$ & - & - & $80 \cdot 24$ \\
\hline $\begin{array}{ll}3-4 \text { months } & \ldots \\
4-5 \quad \text {, } & \ldots \\
5-6 \text { months } & \ldots \\
\end{array}$ & $\begin{array}{r}10 \\
8 \\
3 \\
\end{array}$ & $\begin{array}{r}11 \cdot 36 \\
9 \cdot 09 \\
3 \cdot 40 \\
\end{array}$ & - & $\begin{array}{l}3 \\
4 \\
4 \\
\end{array}$ & $\begin{array}{l}3 \cdot 94 \\
5 \cdot 26 \\
5 \cdot 26 \\
\end{array}$ & - \\
\hline $\begin{array}{c}\text { Per cent. weaned } \\
\text { by end of } 6 \\
\text { months } \\
\end{array}$ & 一 & - & $89 \cdot 86$ & - & - & 94.68 \\
\hline $\begin{array}{l}6-9 \text { months } \\
\text { Per cent. weaned } \\
\text { by end of } 9 \\
\text { months } \\
9-12 \text { months } \\
\end{array}$ & $\overline{6}$ & $\overline{6 \cdot 81}$ & $\begin{array}{c}93 \cdot 26 \\
- \\
\end{array}$ & $\overline{2}$ & $\overline{2 \cdot 63}$ & $\begin{array}{l}97 \cdot 31 \\
- \\
\end{array}$ \\
\hline $\begin{array}{c}\text { Per cent. weaned } \\
\text { by end of } 1 \\
\text { year .. }\end{array}$ & 88 & - & $99 \cdot 86$ & 76 & - & 99.94 \\
\hline
\end{tabular}

TIME AT WHICH BABY WAS WEANED FROM BREAST

It will be seen that an equal proportion of sick and well babies were weaned in the first fortnight. The next fortnight sees the sick babies leading by 14 per cent. This continues till the end of the third month. The proportion thereafter is equalized. 
4. Comparison of duration of breast-feeding in groups of babies with gastro-enteritis and sick babies with other complaints.

(a) Total number of babies with gastro-enteritis

39 sick babies with other complaints 37

Total number of sick babies $\quad$. $\quad \overline{76}$

Age: Actual average age-gastro-enteritis group, 1 month 3 days.

Actual average age, other sick babies, 1 month 21 days.

\begin{tabular}{|c|c|c|c|c|c|c|}
\hline \multirow{2}{*}{$\begin{array}{l}\text { Age at date of } \\
\text { interview }\end{array}$} & \multicolumn{3}{|c|}{$\begin{array}{l}\text { Gastro-enteritis } \\
\text { group }\end{array}$} & \multicolumn{3}{|c|}{ Other sick babies } \\
\hline & No. & $\begin{array}{l}\text { Per } \\
\text { cent. }\end{array}$ & $\begin{array}{l}\text { Per } \\
\text { cent. }\end{array}$ & No. & $\begin{array}{l}\text { Per } \\
\text { cent. }\end{array}$ & $\begin{array}{l}\text { Per } \\
\text { cent. }\end{array}$ \\
\hline $\begin{array}{l}0-2 \text { weeks } \\
2-4 \quad .,\end{array}$ & $\begin{array}{l}\mathbf{0} \\
\mathbf{0}\end{array}$ & - & - & $\begin{array}{l}\mathbf{0} \\
\mathbf{3}\end{array}$ & $\overline{8 \cdot 10}$ & - \\
\hline $\begin{array}{l}\text { Per cent. under } \\
\text { age one month } \\
\text { 1-2 months } \\
2-3 \quad \text {.. }\end{array}$ & $\begin{array}{l}\overline{10} \\
10\end{array}$ & $\begin{array}{l}2 \overline{25 \cdot 64} \\
25 \cdot 64\end{array}$ & - & $\begin{array}{l}7 \\
1\end{array}$ & $\begin{array}{r}-\overline{18 \cdot 91} \\
2 \cdot 70\end{array}$ & $\begin{array}{l}810 \\
-\end{array}$ \\
\hline $\begin{array}{l}\text { Per cent. under } \\
\text { age } 3 \text { months } \\
3-4 \text { months } \quad . \\
4-5 \text {. } \\
5-6 \text { months } \quad . .\end{array}$ & $\begin{array}{l}- \\
2 \\
4 \\
3\end{array}$ & $\begin{array}{r}\overline{5 \cdot 12} \\
10 \cdot 25 \\
7 \cdot 68\end{array}$ & $\begin{array}{c}51 \cdot 28 \\
- \\
-\end{array}$ & $\begin{array}{l}-6 \\
3 \\
4\end{array}$ & $\begin{array}{r}\overline{16 \cdot 21} \\
8 \cdot 10 \\
10 \cdot 81\end{array}$ & $\begin{array}{c}29 \cdot 71 \\
- \\
-\end{array}$ \\
\hline $\begin{array}{l}\text { Per cent. under } \\
\text { age } 6 \text { months } \\
6-9 \text { months }\end{array}$ & $\overline{4}$ & $\overline{10 \cdot 25}$ & $\begin{array}{c}74 \cdot 33 \\
-\end{array}$ & $\overline{7}$ & $\overline{18 \cdot 91}$ & $\begin{array}{c}64 \cdot 83 \\
-\end{array}$ \\
\hline $\begin{array}{l}\text { Per cent. under } \\
\text { age } \ni \text { months } \\
9-12 \text { months .. }\end{array}$ & $\overline{6}$ & $\overline{15 \cdot 39}$ & $\begin{array}{c}84 \cdot 58 \\
-\end{array}$ & - & $\overline{16 \cdot 21}$ & $\begin{array}{c}83 \cdot 74 \\
-\end{array}$ \\
\hline & 39 & - & 99.97 & 37 & - & $\overline{99.95}$ \\
\hline
\end{tabular}

The higher proportion of young infants suffering from gastro-enteritis, as against other conditions, is evident. This preponderance is lost after 6 months.

(b) Duration of breast-feeding (76 sick children) TIME AT WHICH BABY WAS WEANED

\begin{tabular}{|c|c|c|c|c|c|c|c|}
\hline \multirow{2}{*}{\multicolumn{2}{|c|}{$\begin{array}{l}\text { Age when } \\
\text { weaned }\end{array}$}} & \multicolumn{3}{|c|}{$\begin{array}{l}\text { Gastro-enteritis } \\
\text { group }\end{array}$} & \multicolumn{3}{|c|}{$\begin{array}{l}\text { Other sick baby } \\
\text { group }\end{array}$} \\
\hline & & No. & $\begin{array}{c}\text { Per } \\
\text { cent. }\end{array}$ & $\begin{array}{c}\text { Per } \\
\text { cent. }\end{array}$ & No. & $\begin{array}{l}\text { Per } \\
\text { cent. }\end{array}$ & $\begin{array}{c}\text { Per } \\
\text { cent. }\end{array}$ \\
\hline $\begin{array}{l}2 \text { weeks or lk } \\
2-4 \text { weeks }\end{array}$ & & $\begin{array}{r}8 \\
13\end{array}$ & $\begin{array}{l}20 \cdot 51 \\
33 \cdot 34 \\
\end{array}$ & - & $\begin{array}{l}7 \\
9 \\
\end{array}$ & $\begin{array}{l}18.91 \\
24 \cdot 32 \\
\end{array}$ & - \\
\hline $\begin{array}{l}\text { Per cent. wean } \\
\text { by end of fi } \\
\text { month } \\
1-2 \text { months } \\
2-3 \quad \text {.. }\end{array}$ & $\begin{array}{l}\text { ned } \\
\text { irst } \\
\cdots \\
\cdots \\
\cdots\end{array}$ & $\begin{array}{r}\overline{10} \\
4\end{array}$ & $\begin{array}{l}2 \overline{15 \cdot 64} \\
10 \cdot 25\end{array}$ & $\begin{array}{c}53.85 \\
- \\
-\end{array}$ & $\begin{array}{l}\overline{8} \\
2\end{array}$ & $\begin{array}{r}-\overline{21.62} \\
5.40\end{array}$ & $\begin{array}{c}43.23 \\
- \\
-\end{array}$ \\
\hline $\begin{array}{l}\text { Per cent. wean } \\
\text { by end of thi } \\
\text { month } \\
3-4 \text { months } \\
4-5 \\
5-6 \quad . . \\
5\end{array}$ & $\begin{array}{l}\text { eed } \\
\text { ird } \\
\ldots \\
\ldots \\
\ldots \\
.\end{array}$ & $\begin{array}{l}- \\
1 \\
1\end{array}$ & $\begin{array}{l}- \\
2 \cdot 56 \\
2 \cdot 56\end{array}$ & $\begin{array}{c}89 \cdot 74 \\
- \\
-\end{array}$ & $\begin{array}{l}- \\
3 \\
3 \\
3\end{array}$ & $\begin{array}{l}-10 \\
8 \cdot 10 \\
8 \cdot 10\end{array}$ & $\begin{array}{c}70 \cdot 25 \\
- \\
-\end{array}$ \\
\hline $\begin{array}{l}\text { Per cent. wean } \\
\text { by end of } \\
\text { months } \\
6-9 \text { months }\end{array}$ & $\begin{array}{c}\text { sed } \\
\text { six } \\
\ldots \\
\cdots\end{array}$ & $\overline{2}$ & $\overline{5 \cdot 12}$ & $\begin{array}{c}94 \cdot 86 \\
-\end{array}$ & 二 & - & $\begin{array}{c}94 \cdot 55 \\
-\end{array}$ \\
\hline $\begin{array}{l}\text { Per cent. wean } \\
\text { by end of nir } \\
\text { month } \\
9-12 \text { months }\end{array}$ & $\begin{array}{c}\text { ned } \\
\text { nth } \\
\ldots \\
\ldots \\
\end{array}$ & - & 二 & $\begin{array}{c}99.98 \\
-\end{array}$ & $\overline{2}$ & $\overline{5 \cdot 40}$ & 二 \\
\hline & & 39 & - & 99.98 & 37 & - & 99.95 \\
\hline
\end{tabular}

This table shows that gastro-enteritis develops in a higher proportion ( 20 per cent.) of babies weaned early. This preponderance disappears after the sixth month, when the two groups are approximately equal.

\section{Employment of mothers}

(a) Employment during pregnancy:

Total no. of mothers 164 Per

No. employed up to 24th week of pregnancy 12 cent.

$$
\begin{array}{cccccc}
, & , & , & \text { 28th week of pregnancy } & 6 & 3.6 \\
\text {," } & \text { 32nd week of preg- } & & \\
& & \text { nancy and later } & \text {. } & 11 & 6.7
\end{array}
$$

Total number employed after six months of pregnancy

(b) Employment of mother during first six months after birth of child.

Mothers returning to work before child was:

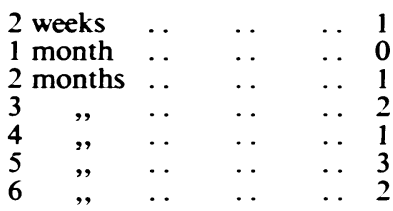

Total returning before child was -

six months of age $\quad . \quad \ldots 10$ or 6.07 per cent.

\section{Comments}

1. The duration of breast-feeding in this group is considerably shorter than in the welfare group. In this group, 34.19 per cent. of the well babies and $19 \cdot 76$ per cent. of the sick babies were breast-fed after the third month, as compared with 49.5 per cent. in the welfare group.

2. It is significant that babies in the sick group were weaned earlier than in the well group; 48 per cent. were weaned by the end of the first month, and 80 per cent. by the end of the third month, as compared with the well group, in which 34 per cent. were weaned by the end of the first month, and 45 per cent. by the end of the third month. After the sixth month, there is no striking difference in the weaning period of the two groups.

3. The 'sick baby' is younger than the 'well baby' group, but there is no evidence that the onset of symptoms of the current illness played a rôle in the period of weaning.

4. The gastro-enteritis group were weaned somewhat earlier than either the 'well group' or the babies ill with other complaints: 53 per cent. were weaned by the end of the third month, as compared with 43 per cent. of other sick babies weaned at the same period.

5 . The percentage of mothers employed during pregnancy was similar to the figure in the welfare group, i.e. 17 per cent. in the former, as compared with $16 \cdot 3$ per cent. in the latter.

6 . The number of mothers employed during the early months after the baby's birth was lower ( 6 per cent. as compared with $12 \cdot 8$ per cent.).

\section{Conclusions}

1. Early weaning is related to the occurrence of gastroenteritis.

2. Early weaning is associated with early infections.

3. There is no suggestion from these figures that weaning is associated with the mother's employment in Birmingham.

4. The usual reason given for weaning is milk failure.

5. The observer gained the impression that the large majority of mothers in both groups were in poor general 
health, with pallor, caries, poor skin tone, nervousness, and fatigue. The observer has had a wide experience with a similar group in Chicago, and finds the lower standard of maternal general health is striking, but does not conclude that war causes are the chief factor.

\section{War-time day nurseries}

Table shows the observations, made in 178 individual enquiries.

DAY NURSERIES (OCTOBER, 1942)

Babies weaned for the following reasons:

$$
\begin{aligned}
& \text { Total } \\
& \text { Milk failed-59 per cent. } \quad \text {. } \quad \ldots \quad \ldots \quad 85 \\
& \text { Weaned to allow mother to work-22 per cent. } 33
\end{aligned}
$$

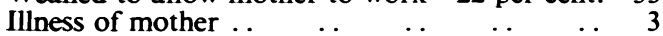

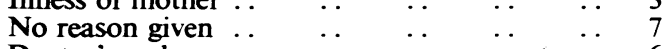

$$
\begin{aligned}
& \begin{array}{llllllll}
\text { Doctor's orders } & \ldots & \ldots & \ldots & \ldots & \ldots & 6
\end{array} \\
& \begin{array}{lllllll}
\text { Breast abscess } & \ldots & \ldots & \ldots & \ldots & \ldots & 6
\end{array}
\end{aligned}
$$

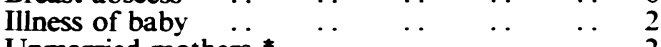

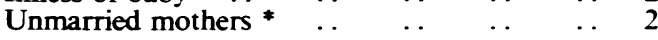

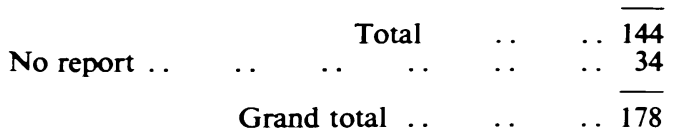

* Baby not usually in war-time nursery.

It will be noted that a high percentage stated ' milk failed." This would seem to indicate difficulties in the breast-feeding. Of those weaned to allow the mother to work, the information must be taken in conjunction with the rising number of unmarried mothers. Although only two mothers are noted as unmarried, the fact that a child is illegitimate is not necessarily known at the nursery.

\section{Final conclusions}

1. In our opinion, war-time conditions have not materially altered the incidence of breast-feeding.

2 . It is evident that very few women are prepared to leave their home to go to work while the baby is under the age of six months.
3. The investigation emphasizes that only 50 per cent. of women are prepared to continue breast-feeding their baby after three months.

\section{SUMMARY OF TABLE 3}

Total number of cases investigated:

$$
\begin{array}{cccc}
\text { First quarter of } 1941 & \ldots & \ldots & 1937 \\
, " \quad, \quad 1942 & \ldots & \ldots & 2698 \\
\multicolumn{2}{l}{\text { Grand total investigated }} \\
\end{array}
$$

Previous child not breast-fed, but success-

ful with later child $\ldots . . . \quad \ldots 15$

1941 Total not breast-fed, or breast-fed

1942 Total not breast-fed, or breast-fed for less than 1 month $\quad . \quad \ldots 7 \cdot 2$

Total 1st babies fed up to and over 3 months1941

Total 2nd498-49.7 per cent. $685-49 \cdot 5$ per cent. 537-57.3 per cent. $\quad 718-54.5$ per cent.

Total . 1035-53.4 per cent. 1403-52 per cent.

Working in 1941

Before confinement .. 16.3 per cent. 20.6 per cent.

After confinement . . 12.8

Anxious to work

$6 \cdot 8$
6

,,

$11.7 \quad$,

DAY NURSERIES: Babies under 6 months in attendance at day nurseries in 2nd quarter of 1942:

$$
\begin{array}{rrrrr}
\text { Total } & \ldots & \ldots & 178 \\
\text { Of these: } & & & & \\
\text { Under } 2 \text { months of age } & \ldots & \ldots & 18 \\
\text { Between } 2 \text { and } 3 \text { months } & \ldots & \ldots & 29 \\
\text { Between } 3 \text { and 4 }, & \ldots & \ldots & 33 \\
\text { Between } 4 \text { and } 4 & , & \ldots & \ldots & 98 \\
\text { Total } & \ldots & \ldots & 178
\end{array}
$$

Only two mothers out of this number have attended the nursery to breast-feed their babies. 